\title{
高周波トランスを用いたスイッチング整流器の 入力電流波形改善
}

\begin{tabular}{|c|c|c|c|c|}
\hline 正 員 & 青 & 木 & 忠 & - \\
\hline 員 & 鍬 & 田 & & 豊 \\
\hline 正 員 & 室 & 山 & 誠 & 一 \\
\hline & 小 & 屋 & 敷 & 徹 \\
\hline
\end{tabular}

\section{Improving Input Current Waveforms in a Switching Mode Rectifier with a High Frequency Transformer}

Tadahito Aoki, Member, Yutaka Kuwata, Member, Seiichi Muroyama, Member, Tohru Koyashiki, Member (NTT)

In recent years, switching mode rectifiers (SMRs) which are composed of a capacitor input type rectifier and a DC-DC converter have been used to supply DC power to various electronic systems. Despite their desirable features such as small-size, light-weight, and high-efficiency, there is a disadvantage in that their input current waveforms include many harmonic components, which could severely influence other systems that $\mathrm{AC}$ power lines in common with the SMR. Conventional method to improve the waveforms uses bidirectional switch modules or three full bridge conversion circuits. However, this method cannot decrease the size, because the number of the switching devices increase.

To solve this problem, a novel SMR with a high frequency transformer has been studied. In it, input 3-phase $A C$ voltage is directly converted into high frequency $A C$, then rectified. Futhermore, low order harmonics in the input current waveforms can be eliminated by controlling the conduction intervals of switches, proportional to the instantaneous input line to line voltage.

This paper describes the configuration of the novel SMR and its operating principle for obtaining sinusoidal input current waveforms as well as discusses the distortion factor characteristics of the input current waveforms.

キーワード：SMR，罢㹡波，制御方法，パワーエレクトロニクス

\section{1.まえがき}

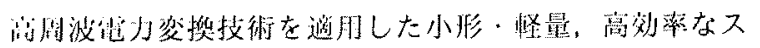

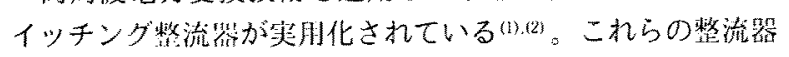
はコンデンサインプット形の全波整流回路とDC-DCコンバー タにより權成されているため，入力電流には多くの高調波成

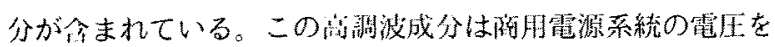

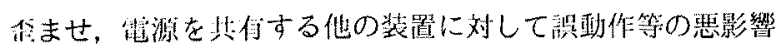
を光えることがある(3)。そのため, 高䙘波電流の発生量を制

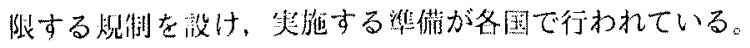

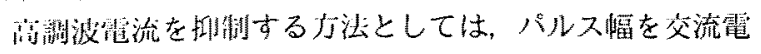
川:の振恎に比例させて制御するPWMコンバータが検討さ
れている(4),(5)。しかし，人出力間を紨縁できる回路形式に

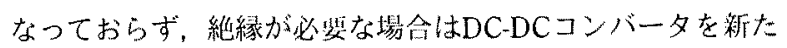

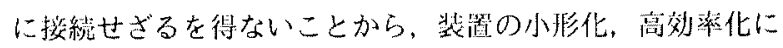

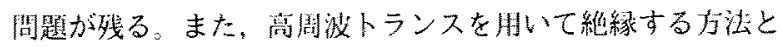
しては，双厅向の肖流制御が可能なスイッチモジュールやダ イオードの直列回路とスイッチング素子をブリッジ接続した

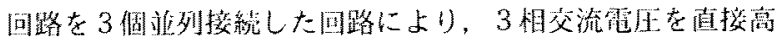
周波交流以変換して絶縁する方法が提案されている(6)(7)。し かし, これらの方法も半導休部品が增扣し, さらにトランス

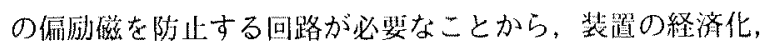
小北化において問題がある。

そこで，著者らは，3相全波整流回路の各ダイオードに泊 
列にスイッチング少子を校綂した閝易な问路形式におい て，3㥵交流電压を直接高同波交流霍压に変換する方法を 川いたスイッチング整流器を提案し，入力霄流波形を正弦 波にすることについて检荆している(8),(9)。

木渝文では，スイッチング整流器の回路辁成を示し，動 訛原理，例御方法について述べる。次に，出力電流と入力

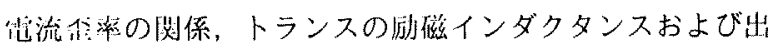
カフィルタのインダクタンスと企摔の閶係について述ベ る。收後に然罪結果について示す。

\section{2. 回路桡成と動作}

$<2.1>$ 回路情成 提案するスイッチング整流器の回路構 成を网1に示す。整流器は，スイッチングによるリプルを 除去するためのコンデンサCi とリアクタLi からなる入力 フィルタ，スイッチS 1 〜 S6を動作させることにより 3 相

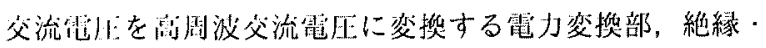
降川:を行う尚夙波トランス，高周波トランスの 2 次側高周 波父流管帅を整流する整流部，整流部出力を平滑するコン デンサCoとリアクタLoからなる出力フィルタより構成さ れている。

$<2.2>$ 回路の基本秒作 本整流器では, 電力供給モ一

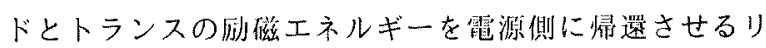
セットモードを䑁り返すことにより，3相交流電压を直接

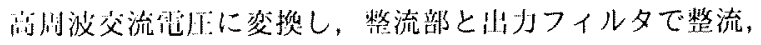

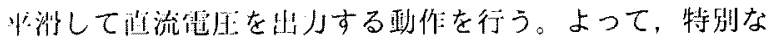

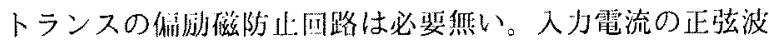
化を㲸るため，電力供給モードにおいては入力 3 相交流電

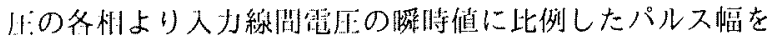
もって必小を值倒侧に倛給する。

ここで，入力フィルタを通した後の入力線間電压を

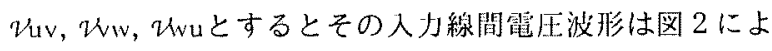

り示される。図 2 から，入力線間電压の大小関係および極 性によって, 電源1周期は12個の区間に分類できる。各区 間の電力供給モードにおいて，真荷側へ電力を供給する相 の順序は種々考えられるが，本諭文では線間電圧の撥時值 の大きい順に電力を供給することとし, 順序決定は電力供 給モードの各開始時点とした。また、リセットモードにお

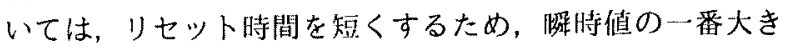
な線間にトランスの成磁エネルギーを帰逯させることとし た。

電力变挨部のスイッチ動作原理を図 3 に示す。なお，図 3 では電力変掺期間（笔力供給モードの期間リリセット モードの期間) Tsが図 2 で示す区間より長くなっている が、これはスイッチの動作をわかりやすくするためであ り，実際は区間に比べて十分に短い。この図を例にとり， 区間 3 における 1 䉓力変換期間のスイッチ動作を詳細に説 明する。区間 3 では, 入力線間電王值が $\mathrm{u}-\mathrm{v}, \mathrm{v}-\mathrm{w}, \mathrm{w}-\mathrm{u}$ の順で小さくなるので, まず，スイッチS1とS5をオンさ せて $\mathrm{u}-\mathrm{v}$ 線間より苗荷側に電力を供給する。次に，又 イッチS3とS5, スイッチS1とS6を順次オンさせてV-W 線 間， $\mathbf{w}-\mathbf{u}$ 線間より負街側に電力を供給する。電力を供給

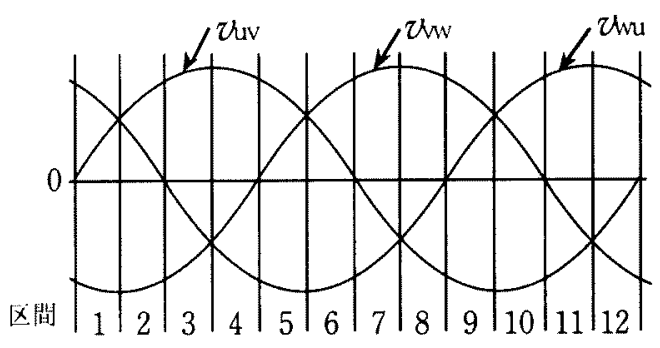

図 2 入力雪压波形

Fig. 2 Input voltage waveforms.

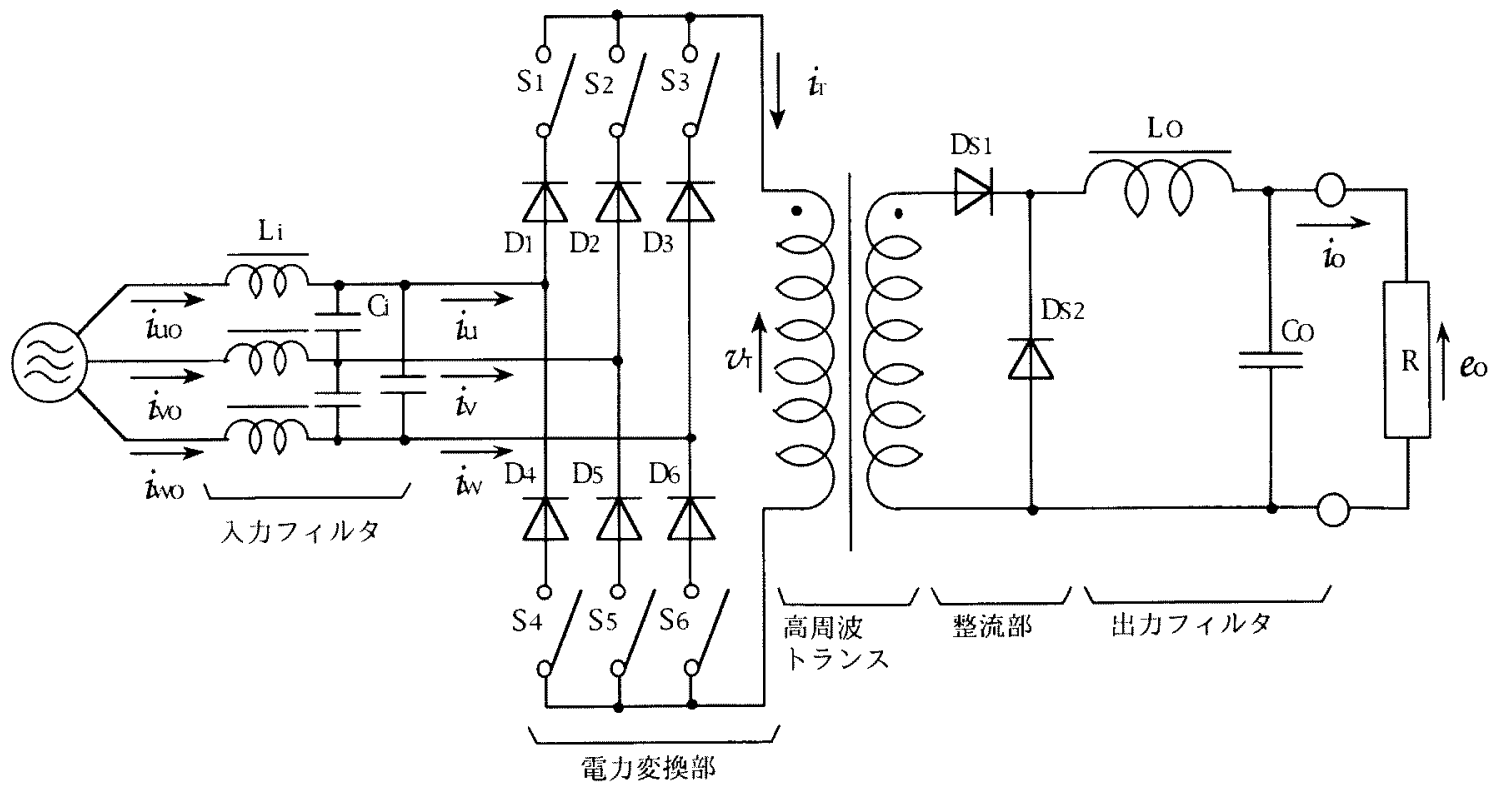

悯 1 スイッチング整流器の櫕成

Fig. 1 Cofiguration of the switching mode rectifier. 

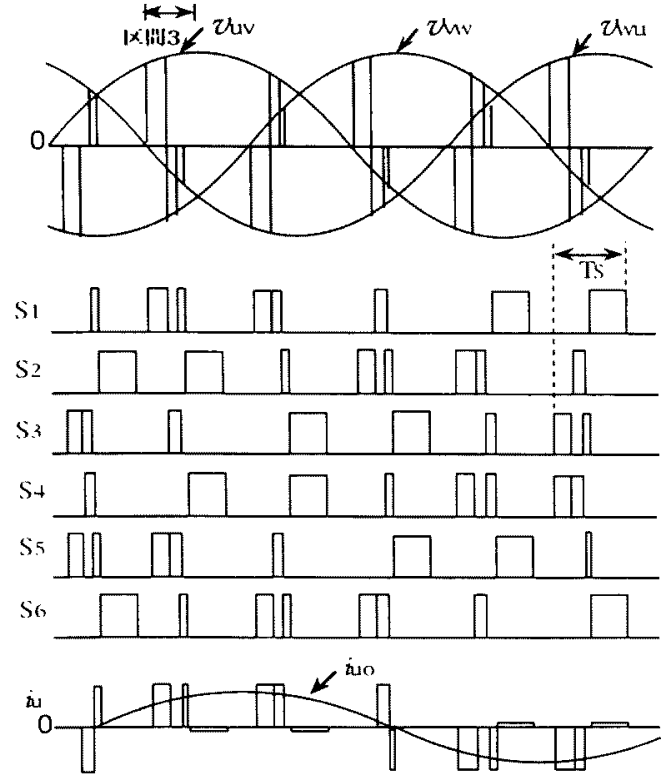

核3 スイッチの動作源理

Fig. 3 Operation principle of switches.

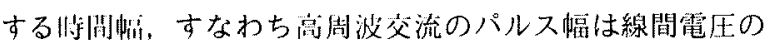

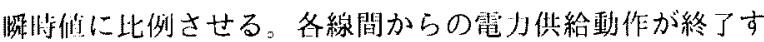
ると，トランスの偏聯を防止するためのリセットモードに 移行する。トランスの㳩磁エネルギ一は，スイッチS2と

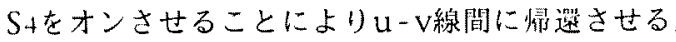

以：，この㳩俳を繰り返すことにより1電力変掺期問の

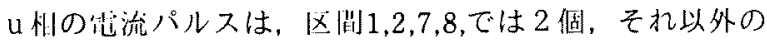

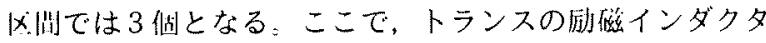
ンスLTおよびサ力フィルタのインダクタンスLOは非常に 人きいと仪这する。この場合，敏力供給モードの電流パル スの波酔们が定，リセットモードの笔流パルスの波高值 がゼロに近い理想状態となり，1電力変掺期間のパルス面

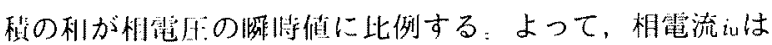
低次の酒調波成分が除去された波形となり，この電流はス イッチングリプルを除去できるフィルタを通すことによつ て法波となる。

$<2.3>$ パルス䏸の決定と出力電国制御力法 パルス幅の

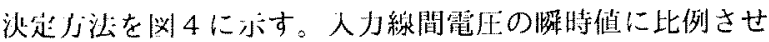
るため, 北力僙緰モードの务パルス湢は，(1)式で示され

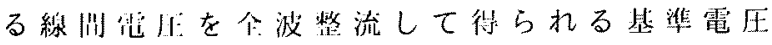
(นuva，认wa，भwua)と(2)式で示されるのこぎり状の電在 恣awを比恔することにより沈定する。

$$
\begin{aligned}
& v_{\text {ux: }}=\left|V_{1} \sin \left(\omega_{1,}\right)\right| \\
& v_{1, \ldots 1}=\left|V_{1} \sin \left(\omega_{0}, t-2 \pi / 3\right)\right| \\
& v_{1 \ldots \ldots}=\left|V_{1} \sin \left(\omega_{1} t+2 \pi / 3\right)\right|
\end{aligned}
$$

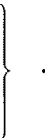

$v_{1+11}=V_{2}$

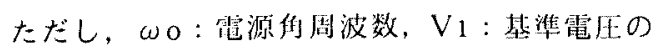
拢情, V2: 比例分数

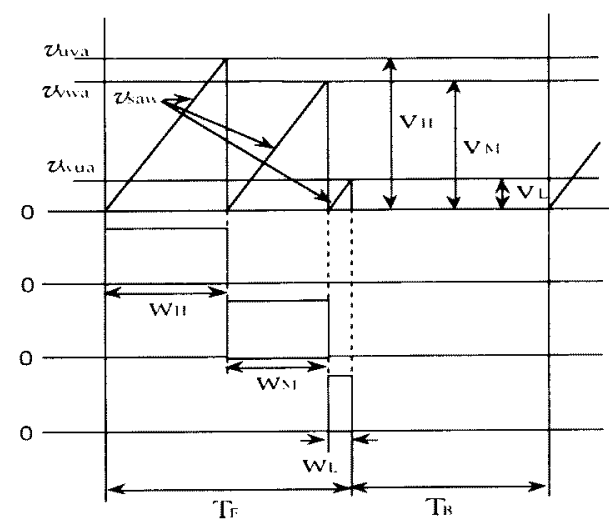

図 4 パルス幅の決定方法

Fig. 4. Generating method of pulse patterns.

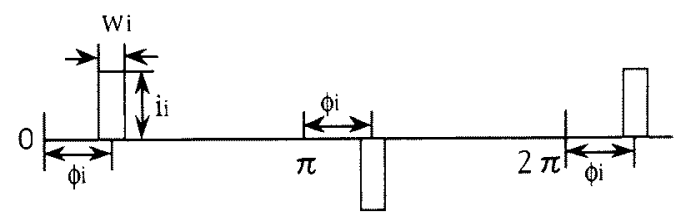

図 5 解析原理を示すパルス列

Fig. 5. Pulse train $P i$ for analysis.

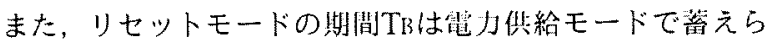

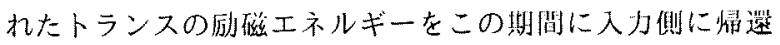

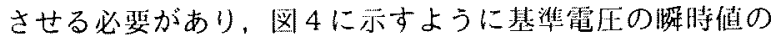
高い順にV\|、VM，Vしとし，それに刘志するパルス㮌を WH, WN,$W_{L}$ とすると，次式を渵足させるように決定する。

$$
T_{13} \geq \frac{V_{11} W_{11}+V_{M 1} W_{N 1}+V_{L} W_{L}}{V_{11}}
$$

出力電压制御は, 霆力供給モードの期間 TFを調整するこ とにより可能なので，デューティ比りを(4)式に示すように 定義すると，このデューティ比を変化させることにより制 御できる。具体的には，のこぎり状波の傾きとなる比例定 数V2を変化させることにより实施する。

$$
\mathrm{D}=\frac{\mathrm{T}_{\mathrm{F}}}{\mathrm{T}_{\mathrm{F}}+\mathrm{T}_{\mathrm{B}}}
$$

\section{3、入力電流の歪率特性}

本スイッチング整流器の入力電流露率は, 動作原理で述べ たようにトランスの阿磁インダクタンス, 出力フィルタのイ ンダクタンス, スイッチング夙波数により変化すると考えら れるので，解析と实驗から入力電流の犁率特性を求める。

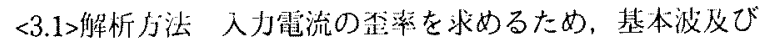
宫調波成分を求める。四 5 に示すようにある基準点から位相 中iに置かれた方䏒波パルスが半周期ごとに正真に出力される 場合, この1組のパルスPiをフーリエ級数により裴すと次式 となる。 


$$
\begin{aligned}
P_{i}= & \sum_{i n=1} \frac{4 i_{i}}{(2 m-1) \pi} \sin \left(\frac{2 m-1}{2} w_{i}\right) \\
& \cdot \cos \left\{(2 m-1)\left(\omega t-\phi_{i}\right)\right\} \quad \ldots
\end{aligned}
$$

ただし、Wi：パルス幅，i1：パルスの波高侹、 $\omega$ ：

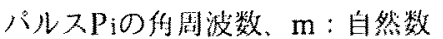

林スイッチング整流器の入力フィルタの出力電流波形を考 えると, 図 3 に示すように霍源周波数 $\mathrm{f} i=50 \mathrm{~Hz}$ て半周期 ごとに正俱に出力さ扎るパルスの集まりである。半周期の 中に個パルスがあるとすると，パルス列iは(5)式を変形 して(6) 武で示さ机るので，第M調波の振幅IMは(7)式と なる。

$$
\begin{aligned}
i_{\mathrm{u}}= & \sum_{\mathrm{i}=1}^{n} \sum_{m-1} \frac{4 \mathrm{i}_{\mathrm{i}}}{(2 \mathrm{~m}-1) \pi} \sin \left(\frac{2 \mathrm{~m}-1}{2} \mathrm{w}_{\mathrm{i}}\right) \\
& \cdot\left\{\cos (2 \mathrm{~m}-1) \phi_{\mathrm{i}} \cos (2 \mathrm{~m}-1) \omega_{0} \mathrm{t}\right. \\
& \left.+\sin (2 \mathrm{~m}-1) \phi_{\mathrm{i}} \sin (2 \mathrm{~m}-1) \omega_{0} \mathrm{t}\right\} \\
\mathrm{I}_{\mathrm{M}}= & \frac{4 \mathrm{i}_{\mathrm{i}}}{\mathrm{M}} \sqrt{\left\{\sum_{\mathrm{i}=1}^{\mathrm{n}} \sin \left(\frac{\mathrm{M}}{2} \mathrm{~W}_{\mathrm{i}}\right) \cos \left(\mathrm{M} \phi_{\mathrm{i}}\right)\right\}_{2}} \\
& +\left\{\sum_{\mathrm{i}=1}^{\mathrm{n}} \sin \left(\frac{\mathrm{M}}{2} \mathrm{~W}_{\mathrm{i}}\right) \sin \left(\mathrm{M} \phi_{\mathrm{i}}\right)\right\}_{2}
\end{aligned}
$$

ただし、M-2m-1

ここで，彗打供給モードの各パルス幅Wiは(1),(2)式か ら求めることができ，幅が求まると基燞点からの位相申が 求まる。リセットモードのバルス愊は(3)式から求まる。

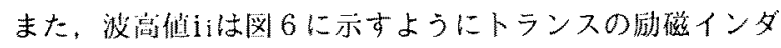
タタンスLTと肪力フィルタのイン゙タタンスLoの大きさ に念して㬨阔と其に変化する。そこで，本解析では波高值 をパルスの川心垈の振腰とし，一定振幅の方形波パルスと して近似する。トランスの淮磁インダクタンスによる変化 分を $\Delta \mathrm{i} n \mathrm{i}$, 出力フィルタのインダクタンスによる変化分を $\Delta \mathrm{i} F \mathrm{i}$ とすると, 変化分 $\Delta \mathrm{i} i$ は $(8)$ 式で示さ执(10), 図6 に示す 各パルスの波融值は(9)式でホさされ。

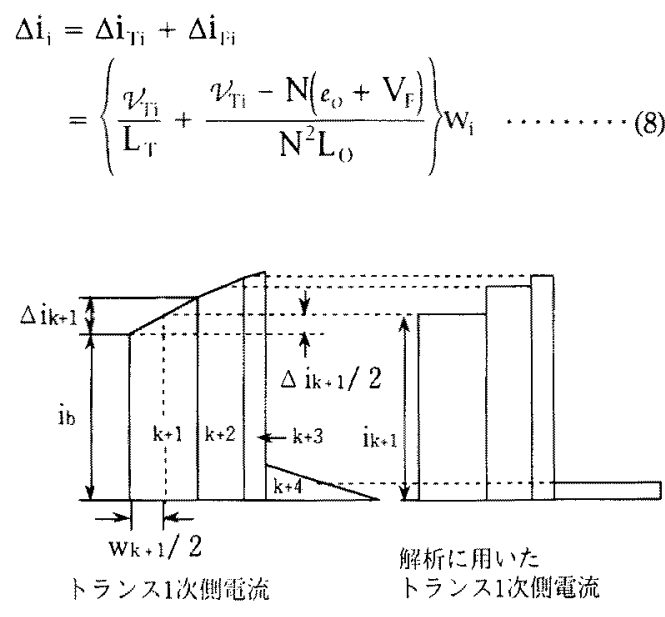

网6トランスの1次側䇝流

Fig. 6. Transformer primary current.

$$
\begin{aligned}
& \mathrm{i}_{\mathrm{k}+1}=\mathrm{i}_{\mathrm{b}}+\Delta \mathrm{i}_{\mathrm{k}+1} / 2 \\
& \mathrm{i}_{\mathrm{k}+2}=\mathrm{i}_{\mathrm{b}}+\Delta \mathrm{i}_{\mathrm{k}+1}+\Delta \mathrm{i}_{\mathrm{k}+2} / 2 \\
& \mathrm{i}_{\mathrm{k}+3}=\mathrm{i}_{\mathrm{b}}+\Delta \mathrm{i}_{\mathrm{k}+1}+\Delta \mathrm{i}_{\mathrm{k}+2}+\Delta \mathrm{i}_{\mathrm{k}+3} / 2 \\
& \mathrm{i}_{\mathrm{k}+4}=\left(\Delta \mathrm{i}_{\mathrm{T}(\mathrm{k}+1)}+\Delta \mathrm{i}_{\mathrm{T}(\mathrm{k}+2)}+\Delta \mathrm{i}_{\mathrm{T}(\mathrm{k}+3)}\right) / 2
\end{aligned}
$$

ただし，暊：トランスの入力電压，VF：整流部ダ

イオードの順方向電瓜降下， $\mathrm{N}$ : トランスの巻数比 ( 1 次/ 2 次)

$$
\mathbf{i}_{\mathfrak{b}}=i_{0} / \mathrm{N}-\left(\Delta \mathbf{i}_{F(k+1)}+\Delta \mathbf{i}_{F i k+2 !}+\Delta \mathbf{i}_{F(k+3)}\right) / 2
$$

$<3.2>$ 歪率特性 入力電压を $\mathrm{AC100V}(3 \phi)$, 出力電压を DC25V，スイッチング周波数FSを $20 \mathrm{kHz}$ とし，表 1 に示 す回路条件で出力電流を変化させた埸合の入力電流证の霆

\section{裴1 回路定数}

Table 1. Values of circuit components.

\begin{tabular}{l|l}
\hline 入カフィルタ & $\mathrm{C}_{\mathrm{i}}=30 \mu \mathrm{F}$ \\
& $\mathrm{Li}_{\mathrm{i}}=800 \mu \mathrm{H}$ \\
\hline \multirow{2}{*}{ 出力フィル夕 } & $\mathrm{Co}_{0}=4800 \mu \mathrm{F}$ \\
& $\mathrm{Lo}_{0}=220 \mu \mathrm{H}$ \\
\hline \multirow{2}{*}{ 高周波トランス } & $\mathrm{N}=16 / 11$ \\
& $\mathrm{LT}=1 \mathrm{~m} \mathrm{H}$ \\
\hline
\end{tabular}

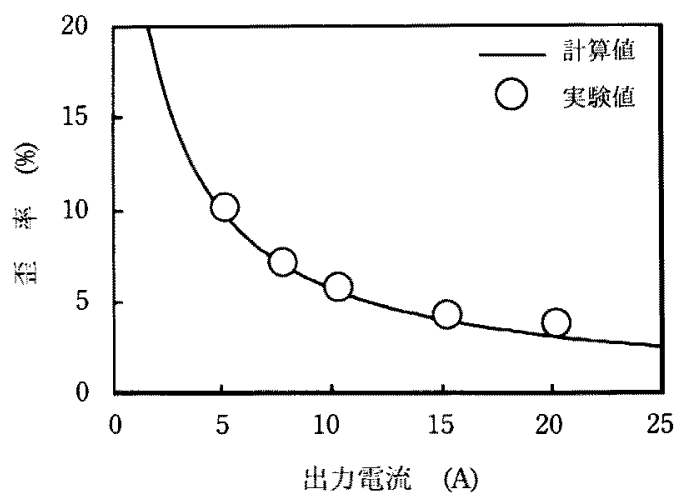

図 7 歪率特性:

Fig. 7. Distortion factor characteristics.

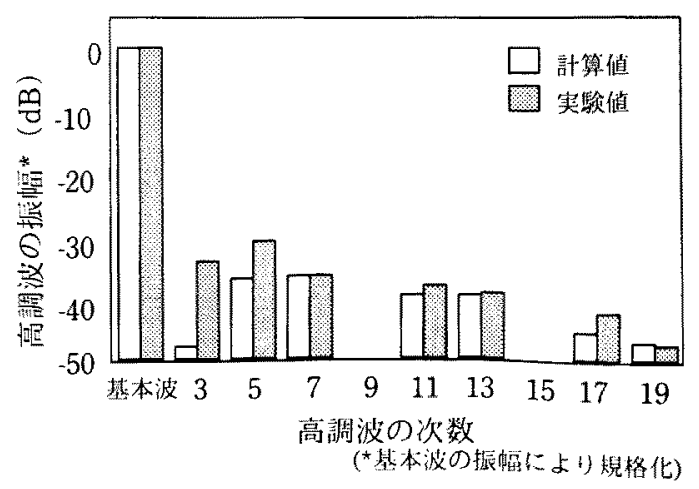

园 8 人力電流の周波数スペクトラム $(i=20 \mathrm{~A})$

Fig. 8. Frequency spectrum of input current.

T. IEE Japan, Vol. 115-D, No. 6, '95 
率特性を図 7 に, 周波数スペクトラムを図 8 に示す。これ らの図より, 歪率は出力電流の減少とともに増加するが, 15A以上で歪率を5\%以下に抑制できることがわかる。基本 波に比べて备低次高調波成分を大幅に小さくできることか ら，入力線阔電压の瞬時值に比例させてパルス幅を制御す るう法により入力電流の低次高調波成分の抑制が可能であ ることがわかる。また，解析值と実験值がほぼ一致してい ることから，解析が妥当であることがわかる。

低次高調波成分が発生する原因を、図 6 および図 9 に示 すトランスの1次側電流波形から考察する。高周波パルス のオン期間に流れる電流值がトランスの励磁インダクタン スと计力フィルタのインダクタンスに応じた傾きを持ち, 备パルスの電流值が変化すること, 帰還電流值が大きいこ とにより理想状態から離れいることがわかる。このことか ら，1 留力変換期間におけるパルス面積の和が相電圧の瞬 時㢟からず机，低次高調波成分が発生していると考えられ る。また, 変化分が高周波パルスの電流值に占める割合 は、出力麗流の減少につれて増加することから, 出力電流 の減少により歪率が大きくなる。

<3.3>インダクタンスと歪率 表 1 に示す回路条件で, スイッチング同波数をパラメータとし, 励磁インダクタン スを変化させた場合の入力電流歪率の解析結果を図 10

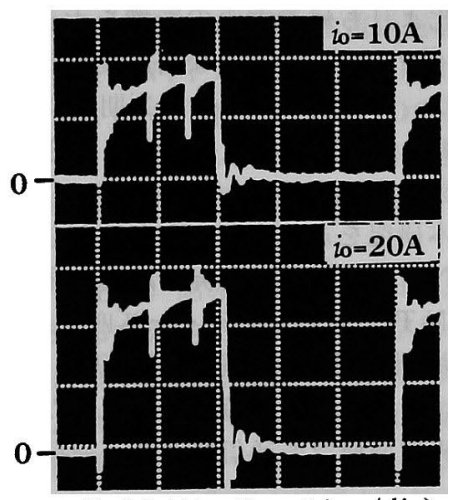

(iт:5A/div, time: $10 \mu \mathrm{s} / \mathrm{div}$ )

図 9 トランスの 1 次側電流波形

Fig. 9. Transformer primary current waveforms.

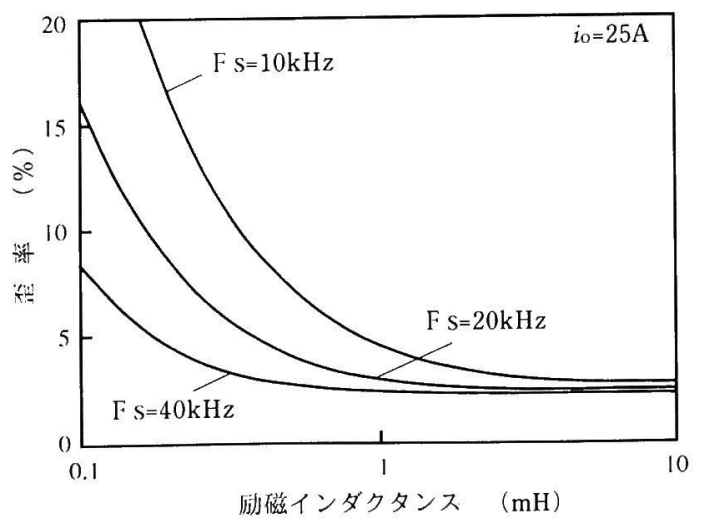

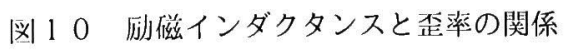

Fig. 10. Exciting inductance vs. distortion factor.
に, 出力フィルタのインダクタンスを変化させた場合の入 力電流歪率の解析結果を図11に示す。前節で述べたよう に, 淤磁インダクタンスと出力フィルタのインダクタンス が大きくなるにつれて, 回路条件が理想状態に近付き, 歪 率が小さくなることがわかる。また, 出力フィルタのイン ダクタンスに対する歪率の変化に比べ, 励磁インダクタン スに対する変化が大きいことから, 歪率は各パルスの電流 值の変化よりも帰還電流值により大きく影響を受けること がわかる。

従って, 本整流器に使用する高周波トランスは, なるべ く大きな励磁インダクタンスを持つように設計し, 帰還電 流值を小さくすることが望ましいと言える。

\section{4. 実験結果}

3.2 項と同じ条件で実験した場合の力率特性, 動作波形 について述べる。

実験機の入力に周波数 $20 \mathrm{kHz}$ まで測定可能な電力計を接 続し, 力涾 (=有効電力/皮相電力) を测定した絬果を図 12 に, 入力線間電圧と入力相電流波形 $(i 0=20 \mathrm{~A})$ を図 13 に示 す。なお，入力フィルタのしゃ断周波数は $1.03 \mathrm{kHz}$ であ る。力率は出力電流の小さい時に低いものの，15A以上で

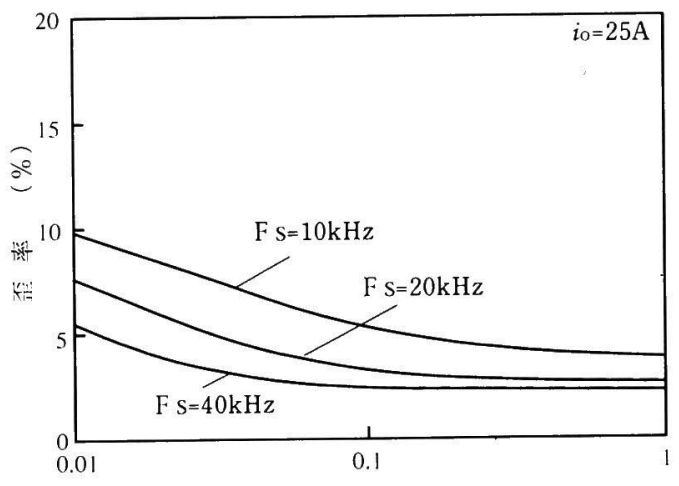

出力フィルタのインダクタンス $(\mathrm{mH})$

図１１＼cjkstart出力フィルタのインダクタンスと歪率 の関係

Fig. 11. Output filter inductance vs. distortion factor.

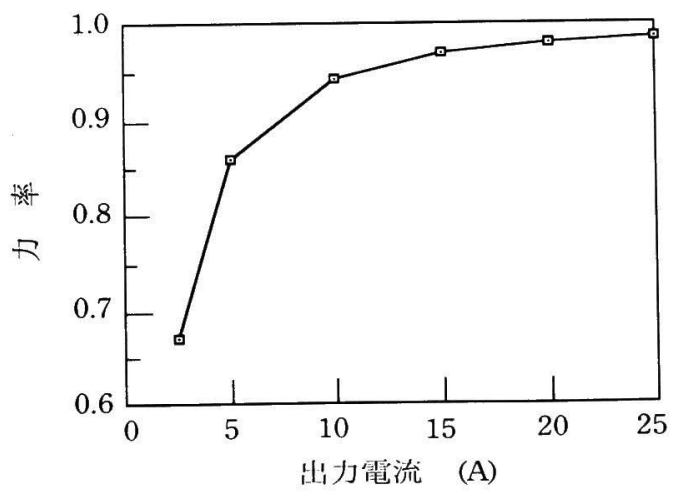

図 12 力率特性:

Fig. 12. Power factor characteristics. 
は0.95以上となっており, 入力電流波形は歪の少ない正弦 波 (露 $=4.2 \%)$ となっている。トランス 1 次側電压波形 を刚14に示す。線間電厓とパルス幅はほぼ比例関係にあ る。また,リセット電圧は線間熋压の一番大きな電圧值に クランプされた後, 零電压になっていることから, トラン スの励磁エネルギーは電源側へ帰還されており，トランス は俯庣磁されないことがわかる。网15に示すトランス 1 次

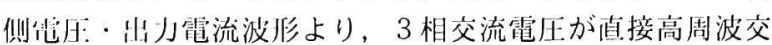
流に亪抁され，脈動の少ない直流出䉓流が得られている

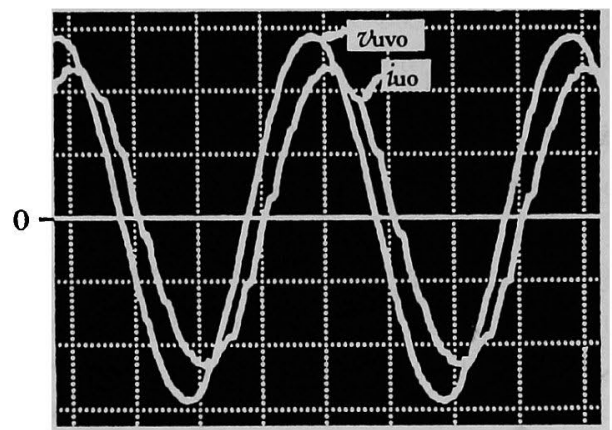

( $\nu_{\text {uvo }}: 50 \mathrm{~V} / \mathrm{div}, i_{\text {uo }}: 2 \mathrm{~A} / \mathrm{div}$, time: $5 \mathrm{~ms} / \mathrm{div}$ )

図 13 入力線間電圧と相電流波形 Fig. 13. Input line to line voltage and input phase current waveforms.

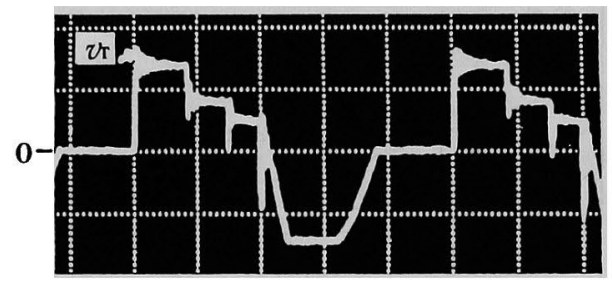

( vr: $100 \mathrm{~V} / \mathrm{div}, \mathrm{time}: 10 \mu \mathrm{s} / \mathrm{div}$ )

脑 14 トランス 1 次侧鍳压波形

Fig. 14. Transformer primary voltage waveform.

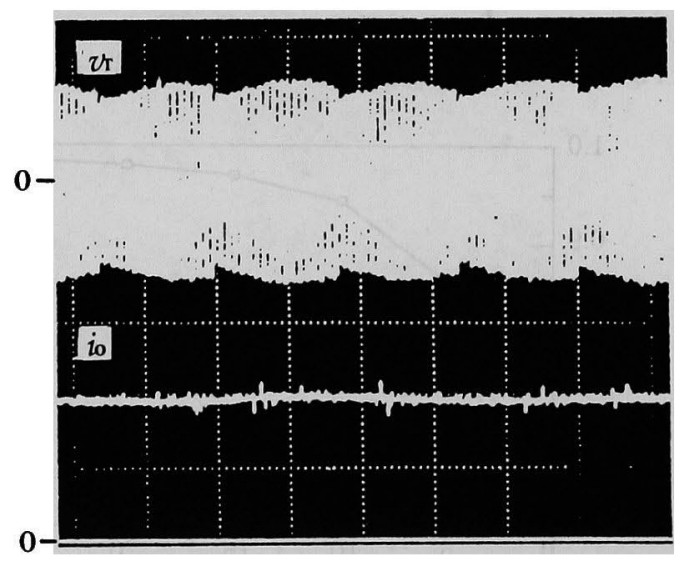

( $\tau_{r}: 100 \mathrm{~V} / \mathrm{div}$, io: $10 \mathrm{~A} / \mathrm{div}$, time: $2 \mathrm{~ms} / \mathrm{div}$ )

|头 15 トランス 1 次側電圧と出力電流波形

Fig. 15. Transformer primary voltage and output DC current waveforms.
ことがわかる。

以上の実験波形から, 提案したスイッチング整流器が原 理通りに動作し, 本制御方法により入力電流の低次高調波 成分を抑制できることが立証できた。

\section{5.まとめ}

3 相全波整流回路の各ダイオードに直列にスイッチング 素子を接続した簡易な回路形式において，3 相交流電圧を 直接高周波交流に変掺し，整流することにより直流電压を 得る新しいスイッチング整流器を提案した。この整流器に おいて, 入力電流の正弦波化について檢討し, 次のことを 明らかにした。

(1)高周波交流のパルス幅を人力線間電压の陊侍値に比例 させて制御する方法により, 入力電流の低次高調波成 分を低減できる。

(2)熋力供給モードとトランスの励磁エネルギーを電源側 に州還させるリセットモードを繰り返すことにより， トランスの偏励磁を防止することができる。

(3)高夙波パルスのオン期間に流机る電流值の変化および 州這電流により，人力電流の歪率は軽負街洔に增扣す る。

(4) 入力電流の歪淬は高周波パルスのオン期間に流れる電 流值の変化よりも州僈電流の影響を大きく受ける。

(5) 淓磁インダクタンスの大きな高周波トランスを用いる ことにより，高周波パルスのオン期間に流机る電流值 の変化幅および帚還電流值を小さくでき, 歪染の一層 の低減が図れる。

終わりに，本研究をまとめるにあたり有益な御助言と御 指導を頂いた N T T 境界領域研究所通信エネルギー佂究部 浅野昇部唇，NＴＴファシリティーズ四元勝一取締役(前 N T T 㙂界領域吥究所通信エネルギー政究部長)に感謝の

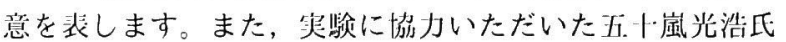
（前ＮＴＴ境界領域吥究所通信エネルギー破究部）に感謝 します。

(半成 6 作 9 月 7 日受付, 平成 7 件 1 月 25 日再受付)

\section{文献}

(1)鉚田䎧・浅見真一郎：「一石フオワードコンバータを 用いた整流器」，信学技派,PE-85,29〜34(昭60-7)

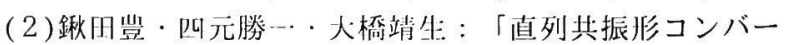
夕回路を脚いた整流器の特性」, 信学諭(B-1),72,41〜 49 (平1-6)

(3) 正田英介：「電力系統における高調波とその対策」,O H M , 90-9, 22〜29(1990)

(4)竹下隆晴・内川喆樹・松井信行：「モデル規範適応同定 器を用いた三㥵PWMコンバータの電流制御」，電学諭 D, 110,384 393(浆2-4)

(5)岩路兹尚・福田詔治：「䉓在抢 PWMコンバータの回路 パラメー夕設計法」、電学諭 D, 112,639 647(平4-7)

(6) S,Manias, A,R,Prasad, P.D.Ziogas : "THREE-PHASE INDUCTOR FED SMR CONVERTER WITH HIGH FRE- 
QUENCY ISORATION, HIGH POWER DENSITY AND IMPROVED POWER FACTOR", IEEE PESC'87 Conf. Rec., 253 263(1987)

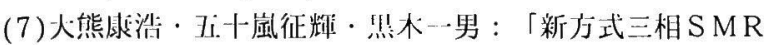
コンバータ」、電学諭 D, 114,544〜550(平6-5)

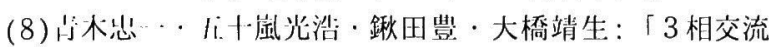
允压泊接変挨形整流器」,昭63年電気学会全大,No.582

(9)T.Aoki, S.Muroyama, M.Igarashi : "A New SwitchedMode Rectifier with Sinusoidal Input Current Waveforms", IPEC-Tokyo, 755〜760(1990)

(10)長谷川莮: 「スイッチング・レギュレータ設計ノウハ ウ」CQ出版社(1985)

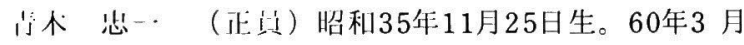

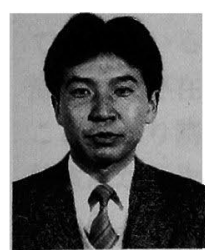
信州大学大学院工学研觉科電気工学専政修 上課程終了。同年4月日本電信電話(㑣) 入 社。垷在, NTT 境界領域研究所主任研究 員。主として, スイッチング整流器, U P $S$ などの通信用電源装置に関する研究に従 j。電子情報通信学会会員, IEEE会員。 踿以䇺 （正員）昭和27年4月24日生。50年3月九

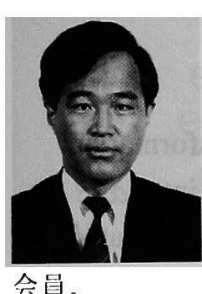
州工業大学電気工学科卒業。同年 4 月日本

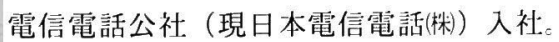
現在, NTT 境界領域研究所主幹研究員。 主として，インバータ，DC-DCコンバー タ, 共振形スイッチング整流器の研究实用 化に從事。電子情報通信学会会員, IEEE 会員。

宅视 誠-

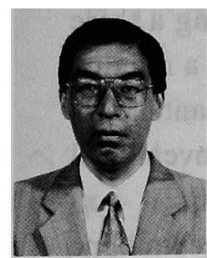

（正員）昭和 25 年1月10日生。47年3月東 京都立大学工学部電気工学科卒策: 同年 4 月日本電信電話公社（現日本電信電話(粦)）

人社。垷在, NTT 境界領域研究所電力装 盅研究グループリーダ。主として，イン バータ, 通信用直流電力供給方式の破究実 用化に従事。電子情報通信学会会員,

IEEE会貝。

小屋数 微 (正員) 昭和 28 年1月 13 日生。52年鹿児島

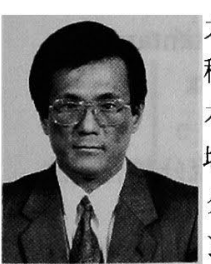

大学大学院工学研究科留父传学尃攻修士課 程終了。同年4月日本笔信贸你公社（現目 本電信電話(粎)）入社。現任：NTT 境界領 域研究所電力システム破聟グループリー ダ。主として，小容量電源，磁気制御形コ ンバータなどの通信用電源装置および給電 方式の侀究实用化に従事。工学博士。電子情報通信学会会 員, 日本忍用磁気学会会員, IEEE会員。 